\title{
A question to the President of the United States, Donald Trump: is it a travel ban, or a Muslim ban, or a travel Muslim ban?
}

\author{
Uma pergunta ao Presidente dos Estados Unidos, Donald \\ Trump: trata-se de uma proibição de viajar, de um banimento de \\ muçulmanos ou de uma proibição de muçulmanos viajarem?
}

\author{
MOHAMED ARAFA* \\ Indiana University School of Law (United States of America) \\ Alexandria University Faculty of Law (Egypt) \\ marafa@iupui.edu \\ Recebido/Received: 18.04.2018 / April $18^{\text {th }}, 2018$ \\ Aprovado/Approved: 25.04.2018 / April 25 $5^{\text {th }}, 2018$
}

\section{Abstract}

Recently, the United States Supreme Court passed a victory to the current President Donald J. Trump by revitalizing parts of a travel ban on individuals from six Muslim-majority countries that he alleged is needed for national security and the interests of the United States but that adversaries criticize and claim as biased and discriminatory. The justices lessened the scope of lower court decisions that had entirely blocked crucial parts of a March 6, 2017 executive order that Trump had said was required to avert terrorism attacks, permitting his temporary ban to go into effect for folks with no strong ties to the United States. In this domain, the court issued its order on the last day of its current term and agreed to hear oral arguments again at a later stage, so it can
Resumo

Recentemente, a Suprema Corte dos Estados Unidos aprovou uma vitória do atual presidente, Donald J. Trump, revitalizando partes de uma proibição de viagem de indivíduos de seis países de maioria muçulmana que ele alegou ser necessária para a segurança nacional ea os interesses dos Estados Unidos. Os adversários criticam e reivindicam como uma medida tendenciosa e discriminatória. Os juízes diminuíram o escopo das decisões de tribunais inferiores que haviam bloqueado totalmente partes cruciais de uma ordem executiva de 6 de março de 2017 que Trump afirmou ser necessária para evitar ataques terroristas, permitindo que sua proibição temporária fosse efetivada por pessoas sem vínculos fortes com a lei para os Estados Unidos. Neste domínio, o tribunal emitiu a sua ordem no último dia do

\footnotetext{
Como citar esse artigo/How to cite this article: ARAFA, Mohamed. A question to the President of the United States, Donald Trump: is it a travel ban, or a Muslim ban, or a travel Muslim ban? Revista de Investigações Constitucionais, Curitiba, vol. 5, n. 2, p. 9-33, mai./ago. 2018. DOI: 10.5380/rinc.v5i2.58990.

"Adjunct Professor of Islamic Law at Indiana University Robert H. McKinney School of Law (Indianapolis, United States of America). Assistant Professor of Criminal Law and Criminal Justice at Alexandria University Faculty of Law (Alexandria, Egypt). Doctor of Juridical Science (S.J.D.), 2013, Indiana University Robert H. McKinney School of Law. Master of Laws (LL.M.) in American Criminal Law and Criminal Justice, 2008, University of Connecticut School of Law (USA). Bachelor of Laws (LL.B.), 2006, Alexandria University, Faculty of Law (“English" Department) (Alexandria, Egypt). E-mail: marafa@iupui.edu.
} 
decide lastly whether the ban is legitimate in a foremost test of presidential powers and controls.

Keywords: travel ban; Muslims; US Supreme Court; human rights; immigration law. atual mandato e concordou em ouvir os argumentos orais novamente numa fase posterior, pelo que pode decidir, por último, se a proibição é legítima em um teste de primeira linha dos poderes e controles presidenciais.

Palavras-chave: proibição de viajar; muçulmanos; Suprema Corte dos EUA; Direitos Humanos; Lei de imigração.

\section{CONTENTS}

1. Introduction and overview; 2. Donald Trump's immigration ban and Barak Obama's 2011 policy: any major differences? 3. The legitimacy of Trump's travel Muslim ban: is it constitutional and legal? 3.1. Literature Legal and Political Background; 3.2. But Was It Legal? What Are the Legal Arguments? 4. The Second Revised Executive Order (Travel Ban) and the Supreme Court's Stance; 5. A new gyration on why the travel ban is unconstitutional and the potential expectations of the U.S. Supreme Court on the Muslim ban case: conclusion; 6 . References.

\section{INTRODUCTION AND OVERVIEW}

After his inauguration on January 20, 2017, President Donald J. Trump signed a controversial executive order on January 27, 2017 stumbling all refugee admissions and temporarily barring individuals from seven Muslim-majority countries.' The move glimmered several protests and legal challenges. After the issuance of that ban, a federal judge in Seattle suspended it nationally, permitting debarred visitors to travel to the US pending an appeal by the administration. ${ }^{2}$ President Trump and his followers say the debatable executive order makes good on election promises to "Make America Great Again." But what is the order, labeled the "Muslim ban" by those standing against it, and

\footnotetext{
GEORGE, Varghese K. Original Travel Ban Should Have Stayed, Says Donald Trump. The Hindu, June 5, 2017. Available at: <http://www.thehindu.com/news/international/original-travel-ban-should-have-stayed-saysdonald trump/article18724064.ece>. (“... Mr. Trump ratcheted up his rhetoric against terrorism soon after the London attack. He first criticized the city's Mayor Sadiq Khan. In another tweet, he said: “We must stop being politically correct and get down to the business of security for our people. If we don't get smart it will only get worse."... "People, the lawyers and the courts can call it whatever they want, but I am calling it what we need and what it is, a TRAVEL BAN!") (last visited Sep. 20, 2017).

2 REINL, James, Trump's Muslim Ban Comes into Effect ("As ban on visitors from six Muslim-majority countries kicks in, US-based families of those affected express resentment"). Aljazeera, June 29, 2017. Available at: <http://www.aljazeera.com/news/2017/06/trump-muslim-ban-redefining-family-170629193344749.html>.

3 FOSTER, Alice. What are the Countries Donald Trump is Banning Travel From? And What Are His Reasons? Express, June 27, 2017. Available at: <http://www.express.co.uk/news/world/761087/Donald-Trump-immigration-ban-what-seven-countries-reasons-US-banning-Muslim-travellers>. Last visited: 20 sept. 2017. “The US Supreme Court has revived parts of Donald Trump's ban immigration from six predominantly Muslim countries in the Middle East and Africa. But which countries does he want to ban and why?") ("In January, the new US President imposed a controversial 90-day ban on travelers from seven countries - Iran, Iraq, Libya, Somalia, Sudan, Syria and Yemen. But after the ban was lifted by the courts, Mr. Trump issued a new ban that removed Iraq from the list of countries affected by the travel ban. Federal judges blocked the new ban ... But the Supreme Court has now revived parts of the ban, allowing it to go into effect for travelers with no strong ties to the US. Donald Trump tweeted: "Great day for America's future Security and Safety, courtesy of the US. Supreme Court. I will keep fighting for the American people, \& WIN!'"'.
} 
who exactly does it affect? In a series of Twitter posts, Mr. Trump may have irreversibly destabilized his attorneys' efforts to convince the Supreme Court to reinstate his executive order restraining travel from six mainly Muslim countries, according to the major legal scholars. ${ }^{4}$ Saying he favored "the original Travel Ban, not the watered down, politically correct version" he had issued, Trump condemned both the Justice Department and the federal courts. ${ }^{5}$ Moreover, he contradicted his own advisers, who have recommended he was causing a pause in travel, by calling the order "what we need and what it is, a TRAVEL BAN!", as he said it would be executed on "certain DANGEROUS countries" and proposed that anything short of a ban "won't help us protect our people!"6 Professor Josh Blackman, a law professor at South Texas College of Law in Houston said that:

There is a reason lawyers generally insist that their clients remain quiet while their cases move forward. "Talkative clients pose distinct difficulties for attorneys, as statements outside the court can frustrate strategies inside the court," "These difficulties are amplified exponentially when the client is the president of the United States, and he continuously sabotages his lawyers, who are struggling to defend his policies in an already hostile arena. I do not envy the solicitor general's office." Even a lawyer with strong ties to the administration said Mr. Trump was hurting his chances in the Supreme Court and undercutting the work of the Justice Department's elite appellate unit [and] he wrote in his own Twitter post, referring to the Office of the Solicitor General and the Supreme Court of the United States. "Sad."

4 See: BBC. Trump Travel Ban: Questions About the Revised Executive Order. BBC News, July 14, 2017. Available at: <http://www.bbc.com/news/world-us-canada-39044403>. Last visited: 20. sept. 2017. “President Donald Trump's second attempt to ban refugees and immigrants from several mostly Muslim countries has faced months of legal to-and-fro. The US Supreme Court is allowing parts of the revised order to be implemented, before it considers the US government's case in full [...] The first executive order, which sparked mass protests and confusion at airports, was halted by the courts... Just hours before a revised version was due to go into effect ...., a judge in Hawaii suspended it nationwide, and it also hit stumbling blocks in several other states before the Supreme Court stepped in.".

5 REINL, James, Trump's Muslim Ban Comes into Effect ("As ban on visitors from six Muslim-majority countries kicks in, US-based families of those affected express resentment"). Aljazeera, June 29, 2017. Available at: <http://www.aljazeera.com/news/2017/06/trump-muslim-ban-redefining-family-170629193344749.html>.

6 FOSTER, Alice. What are the Countries Donald Trump is Banning Travel From? And What Are His Reasons? Express, June 27, 2017. Available at: <http://www.express.co.uk/news/world/761087/Donald-Trump-immigration-ban-what-seven-countries-reasons-US-banning-Muslim-travellers>. Last visited: 20 sept. 2017.

7 EIVEN, Mitch. Trump Promised to Make America Great Again. May be He Will. Then Again? Democracy Guardian, Mar. 2, 2017. Available at: <https://democracyguardian.com/trump-promised-to-make-americagreat-again-maybe-he-will-then-again-6539d7cbe46d>. "Campaign Promise-Ban all Muslims. Once Donald Trump became President, he switched the promise to Travel Ban and Extreme Vetting of Muslims: The campaign promise presupposes that a majority of Americans want Muslims banned from their nation. Opinion polls have consistently proven this supposition boldly inaccurate. Instead, the 'Muslim Ban' promise could only "Make America Great Again", if a pending or an imminent threat made America less great. That threat, that fear, only existed in the mind of Donald Trump and the factless, paranoid, collective psyche of his handlers and the most fervent supporters. The rest of us felt pretty darn confident that the current eighteen to twenty-four month vetting process for refugees (from Muslim majority countries) was pretty effective. Factual media reporting and transparent government information seemed to confirm that reality. There simply has not been 
David B. Rivkin Jr., an attorney in Ronald Regan and George Bush's administrations said that some administration supporters said the court should not consider the tweets. While looking beyond the letter of the order might be suitable in domestic policy, the president has an abler hand in foreign policy. ${ }^{8}$ Taking the oath of the United States presidency marks a thoughtful transition from private life to the nation's uppermost public office, and establishes the singular responsibility and independent authority to protect the welfare of the nation that the Constitution reposes in the president. ${ }^{9}$ According to President Trump twitter' posts, he appeared to say that the latest executive order was of a piece with the former one, issued in January, and with his venerable positions. ${ }^{10}$ In calling the revised order "politically correct,"Trump proposed that his purpose throughout had been to eliminate travelers based on religion and in calling the revised one "watered down," he made it harder for his lawyers to maintain that it was a clean break from the previous one, which had mentioned religion. ${ }^{11}$ In his online posts, President Trump seemed to deceive a confusion of how two branches of the federal gover-

a terrorist attack on US soil by Muslim refugees. The vast majority of attacks since $9 / 11$ were perpetrated by home grown, self-radicalized terrorists. If President Trump were to successfully "Make America Great Again", he would have promised (and implemented) a solution to a real life, terrifyingly dangerous reality; young people radicalized here at home. That's a much tougher nut to crack."

8 EIVEN, Mitch. Trump Promised to Make America Great Again. May be He Will. Then Again? Democracy Guardian, Mar. 2, 2017. Available at: <https://democracyguardian.com/trump-promised-to-make-americagreat-again-maybe-he-will-then-again-6539d7cbe46d>. As a constitutional and legal matter, lawyers in the solicitor general's office filed polished briefs in the Supreme Court and they urged the justices to ignore incendiary statements from Trump during the presidential campaign, comprising a call for a "Muslim ban." Instead, the court should focus on the text of the revised executive order and statements from Mr. Trump after he had taken the inaugural oath to "preserve, protect, and defend the Constitution."

9 EIVEN, Mitch. Trump Promised to Make America Great Again. May be He Will. Then Again? Democracy Guardian, Mar. 2, 2017. Available at: <https://democracyguardian.com/trump-promised-to-make-americagreat-again-maybe-he-will-then-again-6539d7cbe46d>.

10 See MARK, Michelle. It's Not a Muslim Ban: Trump Defends Controversial Executive Order on Refugees as Protests Erupt. Business Insider, Jan. 28, 2017. "President Donald Trump defended his executive order barring travelers from seven Muslim-majority countries from entering the US. "It's not a Muslim ban," Trump told reporters in the Oval Office as he signed several executive orders "It's working out very nicely. You see it at the airports, you see it all over ... Trump's order halted refugee arrivals into the US for 120 days, and it barred citizens of Iraq, Iran, Sudan, Libya, Somalia, and Yemen for 90 days. The order was meant to "protect the United States from foreign nationals entering from countries compromised by terrorism" and implement "a more rigorous vetting process." But the new restrictions caused chaos and confusion at airports across the country, as refugees and even permanent residents of the US were detained by border agents."

11 LING, Sin Yen. Make America Great Again — to the Exclusion of Muslims and Immigrants. Clearinghouse Community, May 6, 2017. Available at: <http://povertylaw.org/clearinghouse/reruns/immigrants $>$. "Donald J. Trump's election as president reminds those of us who identify as immigrants or people of color that America was built on slavery, racism, and white supremacy. No matter how many steps are made toward progress and inclusion, those who are not white are considered the "other" or "foreign." Today exclusionary policies apply not only to Muslims (see, e.g., President Trump's executive order on immigration, commonly known as the "Muslim ban" or the "travel ban") but also to Latinos as the president makes good on his threat to build a border wall and deport "bad hombres." The rhetoric of the Trump campaign and presidency demonizes an entire community. Muslims being characterized as terrorists after 9/11 is analogous to Mexicans being described as "rapists" and "drug dealers"-except that the term "Mexicans" is a stand-in for all noncitizens or immigrants. Trump's campaign slogan, "Make America Great Again," was easily read as making America white or culturally pure again." 
nment work, as his harsh condemnation of the Justice Department was inappropriate, as he also recommended that the Justice Department could ask the Supreme Court to enforce a "much tougher version" of his executive order. ${ }^{12}$

Furthermore, insulting judges is also normally a poor litigation policy but he also posted that "the courts are slow and political!"13 Trump's own staff members had insisted it was not a travel ban, for instance the White House press secretary, spent much time of one early briefing explaining reporters not to call it that: "It's not a travel ban," "When we use words like travel ban, that misrepresents what it is." Meanwhile, the secretary of homeland security, John F. Kelly, also denied the phrase and recited "This is not a travel ban, this is a temporary pause that allows us to better review the existing refugee and visa vetting system."14 Against this succinct backdrop, this article will examine in Part II, the difference between President Trump's executive order(s) and President Obama's executive order and his 2011 policy and its III section, it illustrates the legality of the ban from the legal and constitutional perspectives and will conclude in its final part by the expectations of what is the approach of the United States Supreme Court?

\section{DONALD TRUMP'S IMMIGRATION BAN AND BARAK OBAMA'S 2011 POLICY: ANY MAJOR DIFFERENCES?}

President Donald Trump defended his executive order momentarily banning citizens from seven majority-Muslim countries by raising a policy set by former President Barack Obama in 2011. ${ }^{15}$ He said, "My policy is similar to what President Obama did in 2011

12 LING, Sin Yen. Make America Great Again - to the Exclusion of Muslims and Immigrants. Clearinghouse Community, May 6, 2017. Available at: <http://povertylaw.org/clearinghouse/reruns/immigrants >. The Supreme Court has asked individuals and groups challenging the executive order to file their claims to the government's briefs and those claims will almost definitely rely on Trump's tweets in arguing that the justices should not resuscitate the order.

13 But the court's role is restricted to evaluating the lawfulness of the current order. Omar Jadwat, a lawyer with the American Civil Liberties Union said, "It just adds to the mountain of already existing evidence that the government has had to ask the court over and over to ignore," which represents folks and groups challenging the law. "Blinding the courts to a reality that everyone else is aware of is never an attractive position, but is especially problematic when you have to ignore in real time what's being said by the president of the United States." Neal K. Katyal, who represents Hawaii in a separate challenge to the order, said "there was a yawning gap between Mr. Trump's tweets and his lawyers' filings. The president's statements, before, during and after his inauguration, continually demonstrate what his so-called travel ban is really about ... It's not surprising his story and his tweets don't match up with what the solicitor general has been trying to say in court."'").

14 Trump's posts came as Ms. Conway, one of Trump's advisers went on NBC's "Today" show and chastised the news media for focusing too much on the president's Tweets, calling it an "obsession with covering everything he says on Twitter and very little of what he does as president."

15 QIU, Linda. Why Comparing Trump's and Obama's Immigration Restrictions Is Flawed. PolitiaFact, Jan. 30, 2017. Available at: <http://www.politifact.com/truth-o-meter/statements/2017/jan/30/donald-trump/ why-comparing-trumps-and-obamas-immigration-restri/>. "President Donald Trump blamed the media for misreporting his controversial executive order and said it was an extension of former President Barack Obama's policies. "My policy is similar to what President Obama did in 2011 when he banned visas for refugees from Iraq for six months. The seven countries named in the Executive Order are the same countries previously identified 
when he banned visas for refugees from Iraq for six months," the statement said. "The seven countries named in the Executive Order are the same countries previously identified by the Obama's administration as sources of terror." On the other hand, advocates, legal experts, and former Obama administration officers have since criticized the comparison, arguing that the 2011 immigration boundaries, during which Obama's administration slowed its processing of Iraqi refugee applications, was essentially different in intent and logistics. ${ }^{16}$ In this regard, Trump's prohibition was much wider than the previous administrations and did not respond to a specific threat. ${ }^{17}$ It should be noted that the Obama administration established the policy subsequent to the finding that two men assumed or suspected of making bombs to target American troops in Iraq were living in Kentucky as refugees. ${ }^{18}$ And here are some differences between the two strategies raised by legal scholars.

Within the scope of the ban, Obama did not "ban visas for refugees from Iraq for six months," as Trump said - refugees don't travel on visas, but the Obama's administration intensely slowed the processing of refugee requests and "Special Immigrant Visas (SIV)" program launched, meant for Iraqi interpreters who helped US forces, while it extended its screening procedures. ${ }^{19}$ Moreover, the Obama government reexamined 58,000 Iraqi refugees who had already been admitted to the US, according to a 2012 congressional hearing..$^{20}$ In addition, Eric Schwartz, the former assistant secretary of state for population, refugees, and migration, also disputed Trump's comparison between the two policies, as he mentioned "For several months in 2011, there was a lower level of Iraqi resettlement, as the government implemented certain security enhancements [...] there was never a point during that period in which Iraqi resettlement was stopped, or banned, ..."21

by the Obama administration as sources of terror,"Trump wrote in a Jan. 29 statement. "To be clear, this is not a Muslim ban, as the media is falsely reporting."'

16 FINER, Jon. Sorry, Mr. President: The Obama Administration Did Nothing Similar to Your Immigration Ban. Foreign Policy, Jan. 30, 2017. Available at: <http://foreignpolicy.com/2017/01/30/sorry-mr-president-the-obama-administration-did-nothing-similar-to-your-immigration-ban/>. Last visited: 20 sept. 2017.

17 Idem. See also, QIU, Linda. Why Comparing Trump's and Obama's Immigration Restrictions Is Flawed. PolitiaFact, Jan. 30, 2017. Available at: <http://www.politifact.com/truth-o-meter/statements/2017/jan/30/donald-trump/why-comparing-trumps-and-obamas-immigration-restri/>.

18 Idem. The Obama government conducted a review in 2011 of the vetting procedures implemented to citizens of a single country (Iraq) and then only to refugees and applicants for Special Immigrant Visas (SIVs), created by Congress to assist Iraqis (and later Afghans) who supported the United States in those conflicts.

19 Idem. Much has been made of Trump's call for "extreme vetting" for nationals of certain nations. The entire purpose of the Obama administration's 2011 review was to improve the already strict vetting to which refugees and SIV applicants were subjected. While many of the details are classified, those difficult procedures, which lead to waiting times of 18-24 months for many Iraqi and Syrian refugees, remain in place today and are continually reviewed by interagency officials.

20 Idem. According to several data from the State Department's Refugee Processing Center, 6,339 Iraqi refugees arrived in the US in 2011, fewer than half the numbers admitted in 2010 and in 2012. Jon Finer, who served as chief of staff to Secretary of State John Kerry and was the director of policy planning at the State Department reported that, "While the flow of refugees slowed significantly during the Obama administration's review, refugees continued to be admitted to the United States during that time, and there was not a single month in which no Iraqis arrived here." Id.

21 Idem. 
So, the 2011 policy intended a narrow group of folks: refugees and Special Immigrant Visa applicants from Iraq, but in contrast, Trump's ban targeted a wide net, excluding millions of individuals across seven countries from approximately every sort of accessible visa. ${ }^{22}$ In other words, it applies to seven countries with total population more than 130 million and to almost every category of immigrant other than diplomats, including tourists and business travelers. ${ }^{23}$

Within the intent, the perspective underlying the two presidents' strategies is also a dramatic difference. The reasoning behind Trump's order was roughly described as to "protect the United States from foreign nationals entering from countries compromised by terrorism" and to impose "a more rigorous vetting process." 24 Thus, Trump's order seems proactive, anticipating a probable attack, while Obama's 2011 policy was reactive, responding to a precise threat: the two Iraqi refugees who had managed to resettle in Kentucky. ${ }^{25}$ It should be noted that the Obama's strategy inclined to prioritize individuals who had been convicted of explicit and specific criminal offenses or about whom the US government had specific knowledge (intent) that proposed the person was a threat or about to commit an imminent harm and was not based on nationality. ${ }^{26}$ Trump is correct, though, that the seven countries mentioned in his order had been previously identified by the Obama administration, but those countries - according to the Department of Homeland Security - were named in a 2015 law that revised the US visa-waiver program to "respond to the growing threat from foreign terrorist fighters."27 In other words, while there were delays in processing, there was no absolute ban. Thus far, the Trump government has provided no evidence, nor even declared, that any

22 FINER, Jon. The Obama administration's review was conducted over unevenly a dozen deputies and principals committee meetings, including cabinet and deputy cabinet-level officers from all of the relevant departments and agencies, as the State, Homeland Security, and Justice departments, and the intelligence community. The Trump ban was supposedly drafted by White House politicians and then presented to the applying agencies a fait accompli.

23 Idem

24 Idem.

25 The men had lied about previous terrorism ties on their paperwork for refugee status. In response, and according to the congressional hearing, the Obama government revised the correlated vetting procedures, comprising checking applicants and resettled refugees against certain databases and revising biographic and biometric information.

26 MARK, Michelle. It's Not a Muslim Ban: Trump Defends Controversial Executive Order on Refugees as Protests Erupt. Business Insider, Jan. 28, 2017.

27 PIEPER, Moritz. Donald Trump's Travel Ban and Barak Obama's Visa Restrictions Are Not the Same. NewsWeek, Feb. 1, 2017. Available at: <http://www.newsweek.com/obama-trump-travel-ban-visa-restrictionsthreat-us-551085>. "Donald Trump's executive order on immigration, issued on January 27, 2017, indefinitely bars Syrian refugees from entering the U.S, suspends the admission of all refugees for 120 days and blocks citizens of seven Muslim-majority countries_-Iran, Iraq, Libya, Somalia, Sudan, Syria and Yemen-from entering the country for 90 days. Introduced as a policy to "protect its citizens from foreign nationals who intend to commit terrorist attacks in the United States", the order has provoked a storm of protest worldwide ..." But the plan did not ban the countries' citizens, it just required travelers who had visited those countries since 2011 to apply for a US visa before entering. 
specific information or intelligence led to its draconian and bigotry or discriminating policy.

Therefore, there are several reasons to detest the Donald Trump administration's executive order on "Protecting the Nation from Foreign Terrorist Entry to the United States" that it's hard to know where to start. Scholars have already argued expressively about its brutality in singling out the most susceptible in society; its strategic folly in offending countries and individuals the United States needs to asset it fight terrorism (the apparent goal of the order in the first place); its cynical incoherence in using the September 11 attacks on the World Trade Center, as a justification and then exempting the attackers' countries of origin; its ham-handed execution and ever-shifting explanations for how, and to whom, it applies; and, thankfully, its legal weakness on a slew of soon-to-be-litigated grounds, as well as that it may breach the establishment and equal protection clauses of the U.S. Constitution. ${ }^{28}$ This is not just bad policymaking practice; it led directly to the confusion, adjoining on chaos, that has attended application of the order by agencies that could only start asking questions (such as: "Does this apply to green card holders?") once the train had left the station. ${ }^{29}$

Foreign governments reminded the U.S. president of his international commitments under international human rights law, and international humanitarian law, such as the Geneva Refugee Convention, of which the U.S. is a signatory. ${ }^{30}$ One last thing at this point as a sort of background, Obama's "seven countries" taken out of context. Trump's entitled that the seven countries listed in the executive order came from the Obama government is suitably left unexplained. Soon after the December 2015 terrorist attack in San Bernardino, California, President Obama signed an amendment to the Visa Waiver Program, a statute that permits residents of 38 countries to travel to the United States without gaining visas and gives Americans reciprocal rights in those countries based on the general principles of private international law and reciprocity clauses. ${ }^{31}$ The amendment removed from the Visa Waiver Program dual nationals who were citizens of four countries (Iraq, Iran, Sudan, and Syria) or anyone who had lately

28 In light of all that, Trump and his advisors, in order to justify and normalize the order, have made a series of false or misleading arguments regarding steps taken more than five years earlier by the Obama administration.

29 Protests over the order erupted at John F. Kennedy airport - among many others as Chicago, Dallas, and San Francesco - after two Iraqi refugees who had been granted asylum and were carrying valid visas were detained by border agents and denied entry. Hundreds of protesters, wielding signs that read, "No ban, no wall," and, "Refugees welcome." It's unclear how many travelers have been affected by the ban so far, but refugee attorneys say they have been receiving reports of immigrants and refugees being detained at airports across the country.

30 See UN High Commissioner for Refugees (UNHCR). The 1951 Convention relating to the Status of Refugees: Its Relevance in the Contemporary Context, Feb. 1999. Available at: <http://www.refworld.org/docid/3ae6b3388.html>. Last visited: 20 sept. 2017.

31 PIEPER, Moritz. Donald Trump's Travel Ban and Barak Obama's Visa Restrictions Are Not the Same. NewsWeek, Feb. 1, 2017. Available at: <http://www.newsweek.com/obama-trump-travel-ban-visa-restrictionsthreat-us-551085>. Un High Commissioner for Refugees (UNHCR). The 1951 Convention relating to the 
traveled to those countries and Obama's government added three more to the list (Libya, Somalia, and Yemen), bringing the total to seven. ${ }^{32}$ But this law did not ban anyone from coming to the United States, it's only required a moderately small percentage of individuals to obtain a visa first and to evade penalizing persons who obviously had good reasons to travel to the relevant countries, as this administration used a waiver provided by Congress for certain travelers, including reporters, journalists, aid workers, and officials from international organizations like the United Nations (diplomats). ${ }^{33}$

Thus, the bottom line is that there is no immigration vetting system is excellent, no matter how "extreme." President Obama often said his uppermost priority was keeping Americans safe. In keeping with America's values and ideals, he also worked to create a vetting system that worked more fairly and professionally, mainly for refugees who are - by definition - in harm's condition. Glancing the criticism, now Trump points a finger at Obama. Consequently, President Trump should defend his attitude on its merits, if he can and he should not compare it to his predecessor's.

\section{THE LEGITIMACY OF TRUMP'S TRAVEL MUSLIM BAN: IS IT CONSTITUTIONAL AND LEGAL?}

In the light of all that, the question is who does travel ban affect?

\subsection{Literature legal and political background}

Visitors, students, scientists, family members, even permanent residents with green cards have been stopped at airports around the world, plunging customs and arrival zones into several chaos and disorder. ${ }^{34}$ Former President Barack Obama publicly spoke out against the immigration ban, and acting attorney general Sally Yates was fired after having ordered officials not to enforce the new policy. ${ }^{35}$ Legally speaking, the provocatively label-

Status of Refugees: Its Relevance in the Contemporary Context, Feb. 1999. Available at: <http://www.refworld.org/docid/3ae6b3388.html>. Last visited: 20 sept. 2017.

32 Idem.

33 Idem.

34 MARK, Michelle. It's Not a Muslim Ban: Trump Defends Controversial Executive Order on Refugees as Protests Erupt. Business Insider, Jan. 28, 2017.

35 TAYLOR, Jessica.Obama CriticizesTrump's Travel Ban, Says'Values Are At Stake'. NPR, Jan. 30, 2017. Available at: $<$ http://www.npr.org/2017/01/30/512487565/obama-criticizes-trumps-immigration-ban-heartened-by-protests $>$. "Former President Barack Obama has criticized President Trump's immigration and travel ban issued ... "heartened by the level of engagement"... in opposition to the action. "In his final official speech as President, he spoke about the important role of citizen[s] and how all Americans have a responsibility to be the guardians of our democracy - not just during an election but every day,"... Citizens exercising their Constitutional right to assemble, organize and have their voices heard by their elected officials is exactly what we expect to see when American values are at stake."' See also BOWERMAN, Mary Bowerman. Watch: Sally Yates and Ted Cruz Go Headto-Head on Trump's Travel Ban. USA Today, May 9, 2017. Available at: <https://www.usatoday.com/story/news/ politics/onpolitics/2017/05/09/sally-yates-and-ted-cruz-go-head-to-head-trumps-travel-ban/314018001/> 
led "Visa Waiver Program Improvement and Terrorist Travel Prevention Act" of the December 2015 complicated the visa application process for citizens of Iran, Iraq, Sudan or Syria and made it more problematic for anyone who had visited any of these countries. ${ }^{36}$

It should be noted that that act created discriminatory blocks for access to the U.S. for scholars, academics, persons with dual nationality, or tourists and while the December 2015 Act was not based on a presidential executive order, Obama could have vetoed that congressional piece of legislation, but didn't. ${ }^{37}$ The biased and arbitrary classification of these seven countries as "terror threats" stays the same and Saudi Arabia, or other countries with links to the 9/11 committers are not on the list, interpreting Trump's recreation of the $9 / 11$ terrorist attacks in the executive order vague at best. ${ }^{38}$ Under the new norms, the U.S. government is detaining folks that have already experienced lengthy vetting procedures. ${ }^{39}$ Implementing a blanket travel ban against entire nationalities not only transgresses the US commitments made under the umbrella of international law and is controversial constitutionally, it is also considered as irresponsible policy. ${ }^{40}$ Jihadists and extreme Islamists groups like $D a^{\prime}$ esh (ISIS) are already celebrating the new travel ban as a propaganda success, strengthening their claim that the U.S. is waging a war on Islam, regardless of Trump's attempts to emphasize that the travel ban is "not about religion."41

\footnotetext{
"Yates was fired as acting attorney general for refusing to carry out the President's first iteration of a travel ban ... During a Senate hearing ..., Cruz questioned Yates over her refusal to carry out the president's travel ban on citizens from seven Muslim-majority countries. Cruz read a section of the Immigration and Nationality Act, which allows the president the power to bar immigrants from the country if it's in the best interest of the country. "Would you agree that is broad statutory authorization," Cruz asked. Yates fired back that she was familiar with the Immigration and Nationality Act (INA) and spouted out another statute. "I am also familiar with an additional provision of the INA, that says no person shall receive preference or be discriminated against in issuance of a visa because of race, nationality or place of birth," she said. "That I believe was promulgated after the statute you just quoted and that's been part of the discussion with the courts, with respect to the INA, was whether this more specific statute trumps the first one you just described."

36 The limitations intended to avert individuals with ties to countries thought to pose a terror threat from using the Electronic System for Travel Authorization to travel to the U.S. with minimal screening.

37 In this respect, Yemen, Libya, and Somalia were added in February 2016 as "countries of concern" by the Department of Homeland Security, and it was this list of seven countries mentioned in Trump's executive order.

38 Neither are countries like Turkey or United Arab Emirates, in which the Trump Organization has done business.

39 TAYLOR, Jessica. Obama Criticizes Trump's Travel Ban, Says 'Values Are At Stake'. NPR, Jan. 30, 2017. Available at: <http://www.npr.org/2017/01/30/512487565/obama-criticizes-trumps-immigration-ban-heartened-by-protests $>$.

40 Id. BOWERMAN, Mary Bowerman. Watch: Sally Yates and Ted Cruz Go Head-to-Head on Trump's Travel Ban. USA Today, May 9, 2017. Available at:<https://www.usatoday.com/story/news/politics/onpolitics/2017/05/09/ sally-yates-and-ted-cruz-go-head-to-head-trumps-travel-ban/314018001/>.

41 ARAFA, Mohamed. Vive la République, Vive la France: Macron's Foreign Policy in Muslim and Middle Eastern World. Jurist Commentary, June 22, 2017. Available at: <http://www.jurist.org/forum/2017/06/ Mohamed-Arafa-vive-la-republique.php>. "He will never ever call for shutting down Muslims from entering France or mosques (other Islamic institutions) to fight what President Trump called "radical Islamic terrorism", as he mentioned during his campaign that "Islam hates us" and he "called for a total and complete shutdown of Muslims entering the United States..."
} 
Concerning Iran, the new rules have specific political implications. The U.S. committed itself to "refrain from any policy specifically intended to directly and adversely affect the normalization of trade and economic relations with Iran" as part of a nuclear agreement with Iran reached in July 2015. The December 2015 changes to the U.S. visa program had already been criticized as breaching the agreement's spirit. ${ }^{42}$ As the order was drafted without inter-agency discussions with Homeland Security, the Justice, State, or Defense departments, it is not completely obvious whether the "incompetence mitigates the malevolence" or whether the political signals are deliberate. Law professors along with legal experts have already argued that Trump's order, is "unconstitutional" and represent a huge "[v]iolation of international law."43

But what is the order, dubbed the "Muslim Ban" by those rallying against it, and who exactly does it affect? So, the first inquiry should be, what is the order? This first order brings in a suspension of the US Refugee Admissions Program for 120 days; an indefinite ban on Syrian refugees, and anyone arriving from seven Muslim-majority countries - Iraq, Syria, Iran, Libya, Somalia, Sudan, and Yemen - faces a 90-day visa suspension, but some visa categories, such as diplomats and the UN, are not included in the suspension. ${ }^{44}$ Further, the order also introduces a cap of 50,000 refugees to be accepted in 2017, against a limit of 110,000 set by former President Barack Obama; priority will be given to religious minorities facing persecution in their countries (e.g. Christians in Syria as Trump singled out) and exceptions could be made on a case-by-case basis. ${ }^{45}$ Under the same executive order, Green Card holders - permanent legal US residents - from the seven countries were originally subject to the same restrictions, causing widespread concern and confusion. ${ }^{46}$ However, the legal counsel to the president, then issued a

\footnotetext{
42 With Iranian researchers, scholars, businessmen, and family members now stranded at airports and denied entry to the U.S, so the U.S. now is taking steps that destabilize initiates made in the nuclear deal. It has reinforced Iranian critiques and toughened suspicions about the trustworthiness of U.S. obligations and in retaliation, Iran has already announced that it will ban U.S. visitors. So, in addition to the carefully prepared security argument, the new travel ban is also a strategy that weakens the agreement made with Iran and is hence in line with Trump's criticism of "one of the worst deals" he has ever seen negotiated.

43 CARASIK, Lauren. The Muslim Ban: Did Trump Really Win? The US Supreme Court's Decision Does Not Put Trump's Original Travel Ban Fully in Effect. Here is Why. Aljazeera, June 27, 2017. Available at: <http://www. aljazeera.com/indepth/opinion/2017/06/muslim-ban-trump-win-170627090639940.html>. "Until the Court issues its final decision, the ban "may not be enforced against foreign nationals who have a credible claim of a bona fide relationship with a person or entity in the United States." That connection would allow those with familial ties and students and employees to enter. But for those who cannot satisfy the requisite connection, the Court held, "the balance tips in favor of the Government's compelling need to provide for the Nation's security." 44 See Executive Order No. 13769 in the Federal Register, Protecting the Nation from Foreign Terrorist Entry into the United States (signed by Donald J. Trump on January 27, 2017), The White House, The Office of Press Secretary, Jan. 27, 2017, https://www.whitehouse.gov/the-press-office/2017/01/27/executive-order-protecting-nation-foreign-terrorist-entry-united-states (last accessed Sep. 20, 2107).

45 Id. See, e.g., Everson v. Board of Ed. of Ewing Twp., 330 U.S. 1, 15 (1947).

46 The Department for Homeland Security issued a statement saying that permanent legal residents would be determined on a case-by-case basis.
} 
memo saying the travel ban did not apply to lawful permanent residents of the United States. ${ }^{47}$ The government claimed over and over again that this order is not about religion but about terror and keeping the country safe, as there are over 40 various countries internationally that are majority Muslim that are not affected by this legitimate presidential order. ${ }^{48}$

\subsection{But was it legal? What are the legal arguments?}

This is being passionately challenged through the US court system, with dozens of lawsuits filed, and the issue ended up in the Supreme Court. It began as a Seattle federal judge suspends the order nationwide, in response to a challenge by the Washington State attorney general, who argued that the executive order violated a clause in the US Constitution that prohibits the favoring of one religion over another. ${ }^{49}$ Then and at later stage, a three-judge panel in the same court rules unanimously against reinstating the ban, after hearing arguments from lawyers from the Department of Justice and Washington State. ${ }^{50}$

In the past, the US used to ban entrants from specific countries and entire regions. But in 1965, the US Congress enacted and passed the Immigration and Nationality Act which said that no person could be "discriminated against in the issuance of an immigrant visa because of the person's race, sex, nationality, place of birth or place of residence. ${ }^{151}$ So, the exclusion of all Syrians would be sufficient to challenge or remedy Trump's order in the courts and the fact that they are all Muslim nations lends weight

47 CARASIK, Lauren. The Muslim Ban: Did Trump Really Win? The US Supreme Court's Decision Does Not Put Trump's Original Travel Ban Fully in Effect. Here is Why. Aljazeera, June 27, 2017. Available at: <http://www. aljazeera.com/indepth/opinion/2017/06/muslim-ban-trump-win-170627090639940.html>. supra note 44. See 8 U.S.C. § $1182(\mathrm{f}) \& 8$ U.S.C. § $1185(\mathrm{a})$.

48 While announcing the plan, Trump cited the attacks of September 11, 2001. But none of the 19 hijackers who committed the attacks came from countries included in the suspension. They were from Saudi Arabia, the United Arab Emirates (UAE), Egypt, and Lebanon. Some pointed out that the list did not include countries where President Trump had business interests, like Saudi Arabia and other areas in the Gulf region.

49 BAUMANN, Lisa. Seattle Judge Who Halted First Trump Travel Ban Not Ready to Rule on Second One Originally. The Associated Press, Mar. 11, 2017. Available at: <http://www.seattletimes.com/seattle-news/seattlefederal-judge-not-ready-to-rule-on-blocking-new-travel-ban/>. U.S. District Judge James Robert said in an order that motions or a complaint over the revised ban need to be filed before he can decide) ("A federal judge in Seattle who issued the order temporarily halting nationwide implementation of President Donald Trump's initial travel ban said ... that because of procedural reasons he won't immediately rule on whether his restraining order applies to the new travel ban [. . .] saying the new version discriminates against Muslims and raises the same legal issues as the original." A request by Trump's administration for an immediate reinstatement of the order is rejected by the $9^{\text {th }}$ Circuit Court of Appeals in San Francisco, California.

50 In a series of tweets since the Seattle ruling, Trump has criticized the suspension, saying the ruling came from a "so-called judge," and that the courts were "making the job very difficult!" and later describing the courts as "so political." After the San Francisco appeals court decision, he tweeted "SEE YOU IN COURT."

51 See United States: Immigration and Nationality Act (last amended March 2004) [United States of America], June 27, 1952, X (8 U.S. Code Chapter 12: 8 U.S.C. § 1182(f)). 
to the critics' argument that the order is "anti-Muslim." ${ }^{52}$ On the other hand, supporters of Trump's order mentioned the post-9/11 attacks and the ability of the administration to take measures to protect national security and they cited the president's powers curtailing from a 1952 law on "Inadmissible Aliens" to "suspend the entry" of "any class of aliens" "that he/[she] finds are detrimental to the interest of the US." ${ }^{33}$ They also suggested that the US presidents can set aside the 1965 law and the most cited example is that of President Jimmy Carter who barred some Iranians during the 1980 hostage crisis. ${ }^{54}$

\section{THE SECOND REVISED EXECUTIVE ORDER (TRAVEL BAN) AND THE SUPREME COURT'S STANCE}

President Donald Trump's second attempt to bar refugees and immigrants (or even non-immigrants) from several mostly Muslim countries has faced months of legal to-and-fro. ${ }^{55}$ It should be noted that the US Supreme Court - recently - is permitting parts of the revised order to be applied, before it considers the US government's case in full. ${ }^{56}$ The first executive order, which flashed mass demonstrations, confusion at airports, and polarized the nation deeply since a long while, was stopped by the courts. ${ }^{57}$ The original

52 CARASIK, Lauren. The Muslim Ban: Did Trump Really Win? The US Supreme Court's Decision Does Not Put Trump's Original Travel Ban Fully in Effect. Here is Why. Aljazeera, June 27, 2017. Available at: <http://www. aljazeera.com/indepth/opinion/2017/06/muslim-ban-trump-win-170627090639940.html>. See also Washington v. Trump, 2017 WL 462040 at *2 (W.D. Wash. Feb.3, 2017).

53 THE WHITE HOUSE. Executive Order No. 13769 in the Federal Register, Protecting the Nation from Foreign Terrorist Entry into the United States (signed by Donald J. Trump on January 27, 2017). The Office of Press Secretary, Jan. 27, 2017. Available at: <https://www.whitehouse.gov/the-press-office/2017/01/27/executive-order-protecting-nation-foreign-terrorist-entry-united-states>. Last accessed: 20 sept. 2017.

54 Civil and human rights groups say Trump's order targeted Muslims because of their faith and that no refugees had been convicted of terrorism-related crimes. They also said that the most recent attacks in the US were carried out by US nationals or citizens from the countries not included in the travel ban. For instance, Fort Lauderdale airport shooting (January 2017): A US citizen; Orlando nightclub shooting (June 2016): A US citizen with Afghan parents; San Bernardino shooting (December 2015): A US citizen with Pakistani parents, and a Pakistani citizen; Chattanooga shootings (July 2015): A Kuwait-born US citizen; Charleston church shooting (June 2015): A US citizen, and Boston Marathon bombing (April 2013): Two Russian citizens with Chechen ethnicity.

55 See THE WHITE HOUSE. Executive Order No. 13780 in the Federal Register, Protecting the Nation from Foreign Terrorist Entry into the United States (signed by Donald J. Trump on January 27, 2017). The Office of Press Secretary, Mar. 6, 2017. Available at: <https://www.whitehouse.gov/the-press-office/2017/01/27/executive-order-protecting-nation-foreign-terrorist-entry-united-states>. Last accessed: 20 sept. 2017.

56 VOGUE, Ariane. Supreme Court Says Grandparents, Relatives Can Enter US Despite Travel Ban. CNN, July 19, 2017. Available at: <http://edition.cnn.com/2017/07/19/politics/supreme-court-travel-ban-grandparents/ index.html $>$. "In a loss for the Trump administration, the Supreme Court [...] left intact a lower court opinion that temporarily exempts grandparents and other relatives from President Donald Trump's travel ban. The justices did give Trump a partial win on another issue by lifting an order exempting a category of refugees from the travel ban ... Three conservative justices, Samuel Alito, Clarence Thomas, and Neil Gorsuch, [...] they would have allowed the travel ban to remain in effect as it applies to grandparents, grandchildren, aunts, uncles, nieces, nephews, cousins, brothers-in-law and sisters-in-law."

57 VOGUE, Ariane. Supreme Court Says Grandparents, Relatives Can Enter US Despite Travel Ban. CNN, July 19, 2017. Available at: <http://edition.cnn.com/2017/07/19/politics/supreme-court-travel-ban-grandparents/ index.html >. "In a loss for the Trump administration, the Supreme Court [...] left intact a lower court opinion 
travel ban included Iraq but an exception was made after it - in the second executive order - was pointed out to the administration that numerous interpreters and others who assisted US troops during the war would have been banded from entering the US along in assisting in fighting radical Islamists and defeating terrorist radical groups like ISIS. ${ }^{58}$ Just hours before a reviewed version was due to go into effect, a judge in Hawaii suspended it nationwide, and it also hit stumbling blocks in several other states before the Supreme Court stepped in. ${ }^{59}$ And now, the Supreme Court's fresh decision means that individuals from six mainly Muslim nations and refugees will be temporarily banned from the US unless they have a "credible claim of a bona fide relationship with a person or entity" in the country. ${ }^{60}$ This offers a main exception to the ban that specialists say will significantly reduce the number of people who can be denied entry. ${ }^{61}$

Therefore, persons from Iran, Libya, Somalia, Sudan, Syria, and Yemen unable to validate the "bona fide" connection. ${ }^{62}$ In this respect, the Supreme Court has elaborated some explanation on what this means: "For individuals, a close familial relationship is required" and "as for entities, the relationship must be formal, documented, and formed in the ordinary course, rather than for the purpose of evading" the order. ${ }^{63}$ In

that temporarily exempts grandparents and other relatives from President Donald Trump's travel ban. The justices did give Trump a partial win on another issue by lifting an order exempting a category of refugees from the travel ban ... Three conservative justices, Samuel Alito, Clarence Thomas, and Neil Gorsuch, [...] they would have allowed the travel ban to remain in effect as it applies to grandparents, grandchildren, aunts, uncles, nieces, nephews, cousins, brothers-in-law and sisters-in-law."

58 Idem

59 See Hawaii Judge Dilutes Trump Travel Ban Further By Expanding Family List, The Guardian, July 15, 2017. Available at: <https://www.theguardian.com/us-news/2017/jul/14/trump-travel-ban-family-members-derrick-watson $>$. "The Trump administration has asked the supreme court to block a ruling by a federal judge in Hawaii that diluted his travel ban by vastly expanding the list of family relationships with US citizens that visa applicants can use to get into the country. US district judge Derrick Watson . . . ordered the government not to enforce the ban on grandparents, grandchildren, brothers-in-law, sisters-in-law, aunts, uncles, nieces, nephews, and cousins of people in the US. "Common sense, for instance, dictates that close family members be defined to include grandparents,"Watson said in his ruling. "Indeed, grandparents are the epitome of close family members." Watson also ruled that the government may not exclude refugees who have formal assurance and promise of placement services from a resettlement agency in the US."

60 SHEAR, Michael D.; LIPTAK, Adam. Supreme Court Takes Up Travel Ban Case, and Allows Parts to Go Ahead. The N.Y. Times, June 26, 2017. Available at: <https://www.nytimes.com/2017/06/26/us/politics/supremecourt-trump-travel-ban-case.html>. "The Supreme Court cleared the way ... for President Trump to prohibit the entry of some people into the United States from countries he deems dangerous, but the justices imposed strict limits on Mr. Trump's travel ban while they examine the scope of presidential power over the border. Mr. Trump quickly hailed the court's decision to hear arguments on the travel ban [. . .] that the justices' temporary lifting of some of the legal roadblocks to his ban was a "clear victory" for national security. "As president, I cannot allow people into our country who want to do us harm," Mr. Trump wrote, calling his efforts to limit entry into the country a "suspension" instead of a ban. "I want people who can love the United States and all of its citizens, and who will be hardworking and productive." He later tweeted: "Very grateful for the 9-O decision from the U.S. Supreme Court. We must keep America SAFE!"

61 Idem

62 Idem. See also VOGUE, Ariane. Supreme Court Says Grandparents, Relatives Can Enter US Despite Travel Ban. CNN, July 19, 2017. Available at: <http://edition.cnn.com/2017/07/19/politics/supreme-court-travel-ban-grandparents/index.html>.

63 Id. 
other words, the "bona fide" requirement and explained that when the plaintiff makes "an affirmative showing of bad faith" that is "plausibly alleged with sufficient particularity," courts may "look behind" the challenged action to assess its "facially legitimate justification." In the absence of such "affirmative showing," courts have no choice but to defer to the government's "facially legitimate" reason for the action.

This means a student registered at a US university, or a worker who had accepted an offer of employment in the US or someone invited to, for example, deliver a lecture as a visiting or adjunct professors and scholars would be allowed to enter. ${ }^{64}$ Nevertheless, it also means that anyone trying to engineer a connection with a US organization would be banned, for instance, a non-profit group dedicated to immigration issues may not contact foreign nationals from the nominated countries, add them to client lists, and then secure their entry by requesting injury from their exclusion. ${ }^{65}$ But the Trump government's interpretation of "close familial relationships" was inadequate, and did not comprise grandparents, grandchildren, brothers-in-law, sisters-in-law, uncles, aunts, nephews, nieces and cousins. ${ }^{66}$ Legal scholars and judges said that "common sense" would show that grandparents "are the epitome of close family members," and ruled that the ban should not be enforced on all those family members listed above, as they are not terrorists. ${ }^{67}$ Furthermore, those coming in on tourist visas are expected to face special scrutiny, as they unlike those on work, student or family visas, where the connection will be more evident will have to obviously establish a US relationship and refugees without

64 See BBC. Trump Travel Ban: Questions About the Revised Executive Order. BBC News, July 14, 2017. Available at: <http://www.bbc.com/news/world-us-canada-39044403>. Last visited: 20. sept. 2017. "'Grandparents, not terrorists' Hawaii Attorney General Douglas Chin, who challenged both bans in court, said the Supreme Court ruling endorsed Hawaii's position. "This confirms we were right to say that the Trump administration overreached in trying to unilaterally keep families apart from each other," ... The Supreme Court's decision on the refugee ban could prevent the entry of up to 24,000 refugees connected to a US Resettlement Agency. Mr. Trump's 50,000 cap on refugee admissions for the year, part of the executive order, has already been reached. This latest legal ruling is temporary while the Ninth Circuit Court of Appeals considers the government's appeal against a lower court ruling that upheld Hawaii's challenge to the ban. But Naureen Shah of Amnesty International USA said the decision "jeopardizes the safety of thousands of people across the world including vulnerable families fleeing war and violence."

65 SAMPATHKUMAR, Mythili. Muslim Travel Ban: US Supreme Court to Rule on Donald Trump's Controversial Policy [Campaign promise hangs in balance after President suffers defeats in lower courts]. Independent, June 25, 2017. Available at: <http://www.independent.co.uk/news/world/americas/us-politics/us-supreme-courtdonald-trump-muslim-travel-ban-ruling-a7807791.html>. "The US Supreme Court is set to make a ruling on Donald Trump's controversial travel ban on the last day of its current term. The executive order had put a halt to all travelers from six Muslim-majority countries - Syria, Libya, Iran, Somalia, Sudan, and Yemen - entering the US for 90 days. The Trump administration said the ban was in the best interests of national security. Mr. Trump repeatedly said on the campaign trail: "For a total and complete shutdown of Muslims ... until our country's representatives can figure out what the hell is going on. We have no choice, we have no choice." The White House said vetting processes for visas and those attempting to enter as refugees had to be reviewed and strengthened in those 90 days."

66 Idem

67 Idem 
US connections are also expected to face difficulties. ${ }^{68}$ But the question is, how is the revised order different from the original order? The revised order removed Iraq from the list, after it agreed to boost co-operation with the US, and it also lifted the indefinite ban on Syrian refugees and makes it clear that visa and green card holders from the countries on the list will still be allowed entry, as will dual nationals travelling on a passport from a country not on the list. ${ }^{69}$ Additionally, the revised order also says waivers can be granted on a case-by-case basis, in cases where denying entry would "cause undue hardship."

The second executive order states that each of the six countries is either considered a state sponsor of terrorism by the US or "has been significantly compromised by terrorist organizations or contains active conflict zones" and this "diminishes the foreign government's willingness or ability to share or validate essential information about individuals seeking to travel to the United States", especially after the destruction in their institutional intelligence agencies (police and security enforcement apparatuses, courts, military) to exchange essential and vital information. ${ }^{70}$ Opponents have noted that major attacks such as the 9/11 New York attacks, the Boston Marathon bombing, and the San Bernardino and Orlando nightclub attacks were carried out by people from countries not on the list, such as Saudi Arabia, Kyrgyzstan, and many others or by US -born attackers. ${ }^{71}$ And then, what is the Supreme Court doing next?

The US Supreme Court said it would hear arguments on the legality of the revised ban and the court is currently made up of four liberal and five conservative judges, including Trump's new appointee Justice Neil Gorsuch. ${ }^{72}$ Judges who first suspended -

68 SHEAR, Michael D.; LIPTAK, Adam. Supreme Court Takes Up Travel Ban Case, and Allows Parts to Go Ahead. The N.Y. Times, June 26, 2017. Available at: <https://www.nytimes.com/2017/06/26/us/politics/supremecourt-trump-travel-ban-case.html>. However, the US Committee for Refugees and Immigrants, a non-profit group, said that it was confident it had "an existing relationship with incoming refugees, certified and arranged through the Department of State."

69 Idem

70 See U.S. Supreme Court Allows Partial Travel Ban to Take Effect Pending Appeals in October (90-day ban on travelers from 6 mostly Muslim nations stands, unless people can prove U.S. family connection), The Associated Press, June 26, 2017. Available at: <http://www.cbc.ca/news/world/supreme-court-travel-ban-1.4177987>. "In a statement, Trump called the unanimous decision a "clear victory for our national security," adding that keeping Americans safe is his "number one responsibility."

71 WOLF, Richard; GOMEZ, Alan. Supreme Court Reinstates Trump's Travel Ban, But Only for Some Immigrants. USA Today, June 26, 2017. Available at: <https://www.usatoday.com/story/news/politics/2017/06/26/supreme-court-reinstates-president-trumps-travel-ban/103134132/>. "The Supreme Court agreed to let President Trump's immigration travel ban go into effect for some travelers, reversing the actions of lower federal courts that had put the controversial policy completely on hold. The court also agreed to hear the case involving travelers from six predominantly Muslim countries and international refugees, leaving open the chance that it could reverse [...] verdict if challengers can prove the ban is illegal or unconstitutional."

72 LIPTAK, Adam Liptak; FLEGENHEIMER, Matt, Neil Gorsuch Confirmed by Senate as Supreme Court Justice. The N.Y.Times, Apr. 7, 2017. Available at: <https://www.nytimes.com/2017/04/07/us/politics/neil-gorsuch-supreme-court.html>. "Judge Neil M. Gorsuch was confirmed by the Senate to become the $113^{\text {th }}$ justice of the Supreme Court, capping a political brawl that lasted for more than a year and tested constitutional norms 
and then upheld the suspension - of the first order cited several concerns, as the Justice Department had failed to show the executive order gave enough "notice and a hearing prior to restricting an individual's ability to travel."73 Also, there was "no evidence that any alien from any of the countries named in the order" had committed a terrorist attack in the US. ${ }^{74}$ The exclusion of Syrians in the first order was also problematic, as the Immigration and Nationality Act says no person can be "discriminated." Legal experts said that these bans would cause "irreparable injury" by violating the First Amendment protections against religious discrimination based on the President and his administration's intention was to ban people based on their religion (religious test), even though the administration says this is not the case and that consider a ban on Muslims and therefore unconstitutional. ${ }^{75}$ So, the crucial question in that legal battle, is it a "Muslim Ban"?

In the same vein, a US district judge in Richmond, Virginia ruled the first order was unconstitutional as it had religious bias at its heart and an appellate court in the same state ruled along the same lines on the second travel ban too. ${ }^{76}$ Also, the Hawaii court dismissed the government's claim that the ban is not anti-Muslim, as it targets all individuals from the six countries, irrespective of religion, and the countries themselves represent only a small fraction of the world's Muslim population. ${ }^{77}$ The Court recited "The illogic of the government's contentions is palpable. The notion that one can demonstrate animus toward any group of people only by targeting all of them at once is fundamentally flawed," the court ruling said, highlighted that the countries' populations were between $90 \%$ and $99 \%$ Muslim. ${ }^{78}$ The court also cites statements made by

inside the Capitol's fraying upper chamber. The moment was a triumph for President Trump, whose campaign appeal to reluctant Republicans ... rested in large part on his pledge to appoint another committed conservative to succeed Justice Antonin Scalia, who died in February 2016. "As a deep believer in the rule of law, Judge Gorsuch will serve the American people with distinction as he continues to faithfully and vigorously defend our Constitution."

73 Idem

74 WOLF, Richard; GOMEZ, Alan. Supreme Court Reinstates Trump's Travel Ban, But Only for Some Immigrants. USA Today, June 26, 2017. Available at: <https://www.usatoday.com/story/news/politics/2017/06/26/supreme-court-reinstates-president-trumps-travel-ban/103134132/>.

75 Then, lawyers said and questioned the legality of the move, suggesting the Trump administration cannot override the initial ban with a fresh executive order. Others argued that it is "a Muslim ban by another name"; new ban "remains a discriminatory and unconstitutional attempt to make good on his campaign promise to implement a Muslim ban"; [that] "order is an attack on people based on their religion or national origin", and "We remain unconvinced [the ban] has more to do with national security than it does with effectuating the President's promised Muslim ban."

76 SHEAR, Michael D.; LIPTAK, Adam. Supreme Court Takes Up Travel Ban Case, and Allows Parts to Go Ahead. The N.Y. Times, June 26, 2017. Available at: <https://www.nytimes.com/2017/06/26/us/politics/supremecourt-trump-travel-ban-case.html>

77 Idem

78 WOLF, Richard; GOMEZ, Alan. Supreme Court Reinstates Trump's Travel Ban, But Only for Some Immigrants. USA Today, June 26, 2017. Available at: <https://www.usatoday.com/story/news/politics/2017/06/26/ supreme-court-reinstates-president-trumps-travel-ban/103134132/>. 
President Trump, such as a 2015 press release calling for "a total and complete shutdown of Muslims entering the United States." ${ }^{179}$

\section{A NEW GYRATION ON WHY THE TRAVEL BAN IS UNCONSTITU- TIONAL AND THE POTENTIAL EXPECTATIONS OF THE U.S. SU- PREME COURT ON THE MUSLIM BAN CASE: CONCLUSION}

When judges blocked Donald Trump's second attempt to limit travel from a handful of Muslim-majority countries, the $45^{\text {th }}$ president of the US said the rulings were made "for political reasons" and promised to appeal them "all the way to the Supreme Court." ${ }^{\prime 80}$ In this regard, the President faced an uphill battle and complicated situation in both tribunals: the Ninth Circuit which is commonly described as the most liberal and moderate in America; and with six recent Barack Obama appointees, the Fourth Circuit is no longer a bastion of conservatism or textualism. ${ }^{81}$

"Judicial Restraint" is often in the eye of the beholder; and the labels liberal and conventional don't always fit nicely when it comes to determining cases and the context of Judicial Restraint, Justice Antonio Scalia's brand of originalism/textualism had a philosophical impact on the American jurisprudence, most remarkably in his 2008 Heller decision, his most imperative decision and one in which he used his originalism or textualism perspective. ${ }^{82}$ Justice Scalia found in the Second Amendment not just a collective right but an individual right to bear arms, the Supreme Court's most vital statement on one of the most controversial matters of our times. ${ }^{83}$

79 ARAFA, Mohamed. Vive la République, Vive la France: Macron's Foreign Policy in Muslim and Middle Eastern World. Jurist Commentary, June 22, 2017. Available at: <http://www.jurist.org/forum/2017/06/Mohamed-Arafa-vive-la-republique.php>. But the Justice Department says that a distinction should be made between things said as a candidate and as president. In a bid to address religious discrimination issues, the second order removes a section that said refugees "claims should be prioritized on the basis of religious-based persecution, provided that the religion of the individual is a minority religion in the individual's country of nationality."

so SAMPATHKUMAR, Mythili. Muslim Travel Ban: US Supreme Court to Rule on Donald Trump's Controversial Policy [Campaign promise hangs in balance after President suffers defeats in lower courts]. Independent, June 25, 2017. Available at: <http://www.independent.co.uk/news/world/americas/us-politics/us-supreme-courtdonald-trump-muslim-travel-ban-ruling-a7807791.html>. See Int'l Refugee Assistance Project v. Trump, 857 F.3d 554, 572 (4 ${ }^{\text {th }}$ Cir., 2017); $9^{\text {th }}$ Circuit in California in State of Hawaii v. Trump.

81 Idem. Justice Scalia called his judicial approach (judicial activism) to the Constitution "originalism" or "textualism."The idea of Originalism/Textualism is that the Constitution means no more or less than what it meant to those who originally wrote and ratified it. This is a counter-approach to the "living Constitution" idea where the text is interpreted in light of current times, culture and society. The Constitutional principle is Judicial Restraint. As expressed by Justice John Marshall (1801-1835), a central job of the Court, now known as judicial review, is to say what the law is. No Justice, liberal or conservative, not even Justice Scalia's textualism, sees the Court's interpretive function as simple, robotic application of crystal clear rules to crystal clear facts.

82 See generally SIEGEL, Jonathan R. Siegel. The Inexorable Radicalization of Textualism. University of Pennsylvania Law Review, Philadelphia, v. 158, n. 1, p. 117-178, dec. 2009.

83 Idem 
But as the courts prepare for these hearings, a group of constitutional scholars opposed to Trump's travel restrictions from Iran, Libya, Somalia, Sudan, Syria, and Yemen are urging judges to consider the order in a somewhat different light. The new spin is designed to put the challenge on sounder footing at the circuit courts - and to ready it for a NOT decent trip to the Supreme Court. ${ }^{84}$ Legal scholars filed briefs and memorandums arguing that Trump's executive order is precluded by "the long-settled prohibition on governmental acts based on animus toward a particular religious group." ${ }^{185}$ The evidence that the travel boundaries are rooted in the president's hostile approach, Xenophobic, Islamophobic, and religiously intolerant public statements toward Muslims is nothing new: both rulings on appeal catalogued a host of public statements in which he promised, as, a "total and complete shutdown of Muslims entering the United States" as signal that the executive order far from evolving a legitimate national security interest primarily targets Muslims and thus violates the First Amendment rule barring the "establishment of religion." 86

Legal specialists argues that the lower courts' approach of the executive order is "independently supported" by precedents interpreting the First Amendment's establishment and free-exercise clauses and the Fourteenth Amendment's guarantee of equal protection that have nothing to do with Lemon or McCreary. ${ }^{87}$ In Town of Greece $v$. Galloway, a 2014 case involving public prayer at town-board meetings, Justice Anthony Kennedy drew the line at supplications that "signal disfavor toward nonparticipants or

84 BEYDOUN, Khaled. Donald Trump: The Islamophobia President (Trump rose to power with an Islamophobic campaign and Islamophobia now will become his official policy). Aljazeera, Nov. 9, 2016. Available at: <http:// www.aljazeera.com/indepth/opinion/2016/11/donald-trump-islamophobia-president-161109065355945. html>. "Islamophobia won resoundingly tonight. Instead of the first female president, the United States got its first Islamophobia president. From start to finish, the 2016 presidential election vividly revealed that Islamophobia is alive, and potent and politically resonant as ever. Scapegoating Islam and vilifying Muslims was far more than merely campaign messaging; for Donald Trump, it was a winning strategy. Trump's full-blown Islamophobia resonated deeply with voters. Moreover, it mobilized more than just a fringe or rabid demographic, but a sizable segment of the American polity to cast votes in his favor. Instead of "Islam is peace", Trump declared that, "Islam hates us", giving disaffected bigoted voters exactly what they wanted."

85 JOHNSON, Jenna; HAUSLOHNER, Abigailr. 'I Think Islam Hates Us': A Timeline of Trump's Comments About Islam and Muslims. The Washington Post, May 20, 2017. Available at: <https://www.washingtonpost.com/ news/post-politics/wp/2017/05/20/i-think-islam-hates-us-a-timeline-of-trumps-comments-about-islam-andmuslims/?utm_term=.dc6b9f635ea1>. Last visited: 20 sept. 2017.

86 BEYDOUN, Khaled. Donald Trump: The Islamophobia President (Trump rose to power with an Islamophobic campaign and Islamophobia now will become his official policy). Aljazeera, Nov. 9, 2016. Available at: <http:// www.aljazeera.com/indepth/opinion/2016/11/donald-trump-islamophobia-president-161109065355945. html>.

87 But the Hawaii and Maryland prevented orders were grounded in Lemon v. Kurtzman and McCreary v. ACLU, Supreme Court precedents the scholars acknowledge "remain provocative". Chief Justice John Roberts and Justices Samuel Alito, Anthony Kennedy, and Clarence Thomas have all stated doubts about Lemon; in 1993, the late Antonin Scalia likened the 1971 decision to a "ghoul in a late-night horror movie." As a judge on the Tenth Circuit court in 2009, Justice Gorsuch noted that lower courts had "jettison[ed]" Lemon and the Supreme Court "seemed to eschew it". So, it would seem to be a planned necessity, as the legal challenge to Trump's travel ban is tuned for the higher courts, to sketch an alternative case for its unconstitutionality. 
suggest that their stature in the community was in any way diminished." ${ }^{\prime 8}$ Likewise, in the same case, Justice Alito noted that "discriminatory intent" may turn an otherwise acceptable prayer into a violation of the establishment constitutional clause. ${ }^{89}$

According to George Washington's scholarly writings, speaking out against religious "bigotry", Thomas Jefferson saying, the constitution protects "the Jew and the Gentile, the Christian and Mahometan, the Hindoo and infidel", and James Madison criticizing a law that "degrades from the equal rank of citizens all those whose opinions in religion do not bend to those of the legislative authority", the Supreme Court's rejection of official acts expressing religious animus is "of ancient lineage." ${ }^{\prime 90}$ Constitutional and legal scholars argues that the travel ban's anti-Muslim temperament is apparent in "a review of only post-election and post-inauguration statements by the president and his senior advisors." For example, when he signed the first executive order in January, Trump read its title ("Protecting The Nation From Foreign Terrorist Entry Into The United States") and remarked, "we all know what that means." And after his second order was halted by Judge Watson in Hawaii, Trump called it "a watered-down version of the first order" and said, "I think we ought to go back to the first one." Even if part of the motivation behind the ban is valid, mixing that interest "with forbidden animus", the brief explains, "corrupt[s] and distort[s] it."

Leah Litman, a law professor at the University of California, Irvine, thinks the brief may "bear fruit" if the justices "fairly read and apply precedent according to its best reading." Joshua Matz - the attorney who wrote the brief against President Trump in cooperation with scholars Corey Brettschneider, Micah Schwartzman and Nelson Tebbe - has crafted a persuasive and skillfully targeted argument. In navigating clear of Lemon, citing conservative justices and scholars and prominently quoting the likely swing justice, Kennedy (for whom he clerked), Mr. Matz says that "the rebranding of the case is no mere tactic to attract a Supreme Court majority", "Justices and jurists of

88 See Galloway v. Town of Greece, 681 F.3d 20, 22 (2d Cir. 2012). In the case of Kerry v. Din, 135 S. Ct. 2128 (2015), the Supreme Court elaborated on the "bona fide" requirement and explained that when the plaintiff makes "an affirmative showing of bad faith" that is "plausibly alleged with sufficient particularity," courts may "look behind" the challenged action to assess its "facially legitimate justification."

89 Idem. In their appeal, the plaintiffs dropped the intentional discrimination argument. Thus, the only issue considered by the Second Circuit was whether the town's prayer practice had the effect of establishing religion.

90 And the questions is, does Mr. Trump's travel ban represent animus toward Muslims? On the surface, the executive order is not hostile to any specific religion: Judge Alex Kozinski of the Ninth Circuit, lamenting that his colleagues did not vote to reconsider his court's three-judge panel decision against the president's first executive order. He mocked the approach as an "evidentiary snark hunt." A candidate for office says, "many things on the campaign trail" that are often "contradictory or inflammatory", but "the poor shrub's only intention is to get elected."

91 BEYDOUN, Khaled. Donald Trump: The Islamophobia President (Trump rose to power with an Islamophobic campaign and Islamophobia now will become his official policy). Aljazeera, Nov. 9, 2016. Available at: <http:// www.aljazeera.com/indepth/opinion/2016/11/donald-trump-islamophobia-president-161109065355945. html>. 
all methodological and ideological views agree that the government cannot act on the basis of animus toward any particular religion", "This policy squarely offends that rule." Thus, if the Supreme Court abides by its own long-standing principles, "Trump's order cannot stand." As a result, for a law to be found unconstitutional, it generally must be facially discriminatory. Stated another way, the words of the order must evince discriminatory intent. In this case, the Plaintiffs did not dispute that the second travel ban is "facially neutral in terms of religion." According to the Government, because the travel ban is facially neutral, and it applies in the immigration framework, the "Mandel test", from the case of Kleindienst v. Mandel should apply. ${ }^{92}$ The Mandel test holds that "when the Executive exercises [the power to exclude an alien] on the basis of a facially legitimate and bona fide reason, the courts will neither look behind the exercise of that discretion, nor test it by balancing its justification against the [plaintiffs'] First Amendment interests." ${ }^{\prime 93}$ Because Trump's remarks regarding his incentives for the travel ban leak with religious fanaticism, prejudice, and animus towards Muslims, it is hard to imagine that the Supreme Court would uphold the travel ban. For the Supreme Court to hold otherwise would be to permit government administrators to make clear and express statements regarding their unconstitutional intentions in passing a statute, only to be able to deny those declarations and assert immunity from judicial review because (1) the courts are unable to know precisely what the politician meant when they made a specific statement; and (2) the court is not even permitted to ask or inquire into what they meant.

Trump's opinions are obnoxious and hateful to logic and human experience. Trump's speeches, declarations, and comments cannot be elapsed or ignored and perhaps now is as good a time as any for the current President to absorb the age-old concept that a person's uncontrolled statements can come back to haunt them. The debate over the Trump White House's attitude toward Muslims is more than merely academic. Previous presidents have gone out of their way to say their problems are not with Islam as a faith, if only to serve as a public counterbalance to their use of US military power in or against Muslim nations. "The face of terror is not the true faith of Islam," President George W. Bush said shortly after the 9/11 attacks, "that's not what Islam is all about. Islam is peace." President Obama has made comparable remarks, noting that "it's very important for us to align ourselves with the $99.9 \%$ of Muslims who are looking for the same thing we're looking for, order, peace, prosperity." Expectations are that the U.S. Supreme Court may decide soon whether to stay the injunctions blocking President Donald Trump's Muslim Ban.

\footnotetext{
92 See, e.g., Kleindienst v. Mandel, 408 U.S. 753 (1972).

93 Idem.
} 
There's an old saying, "One bad apple spoils the bunch." This holds true when we discuss both the historical and current general perspective of Americans or Westerns towards Arabs and Muslims. Why have I stated Arabs and Muslim throughout this essay? They are separate and diverse peoples. Not every Arab is a Muslim and not every Muslim is an Arab. What have we seen by tracking U.S. immigration policy throughout history? We have seen that the general attitudes of the U.S. towards non-white, nonChristian people to be extremely negative and highly deserving of the word "animus." U.S. courts of the past adopted and supported these same points of view. Animus against Arabs and Muslims was very obvious in the opinions of U.S. courts who classified them among the "undesirables." This facial or prima facie animus existed until the reforms of U.S. immigration policy in 1965 with the end of national origin quotas and removal of race/whiteness as a consideration for immigration.

However, the policy changes of 1965 were more in response to geopolitical necessity than to actual changes in attitudes towards Arabs and Muslims. While the animus of the 1900's may be lessened, it is still present today. Western communities have a generally negative view of Arab and Muslim people compared to other immigrant and population groups. In time, this animus may have subsided completely, but a few bad apples - Mir Qazi, Ramzi Yousef, Saddam Hussein, Osama bin Laden, al-Q'aeda, and the like have spoiled the basket. Their acts have aided in the rebirthing and maintaining of animus towards Arabic and Muslim peoples. They are not alone in this spoilage. The U.S. must accept some of the blame for allowing these radical groups to promulgate and commit the terrorist acts against humanity which have stricken so much fear and distrust into western society.

Is U.S. immigration policy in the Arab region necessary policy or racial animus? I think it is a combination of both - but the animus is winning right now. The "extreme" tactics and rhetoric promulgated by President Trump and his supporters is a complete showing of animus guised in the veil of legitimate policy. However, given that these groups do exist and that they are a real threat to all persons - not just westerners - legitimate, intelligent policies must be in play to minimize the damage they cause until humanity learns to live with itself peacefully. These policies must be consistent across all races, faiths, and classes of immigrant. The "extreme vetting" of persons from certain states only serves the message of extremists - the U.S. is racist beast that disdains all non-white, non-Christians.

The U.S. is a beautiful place to live with so much promise. When American or westerns call themselves the "Melting Pot," They must ask if they mean this sincerely or not. Do really, they welcome all faiths and races or only those that conform to their certain points of view? In other words, must one assimilate to be part of the melting pot or will they forget animus of the past? I hope so. The world is a much more beautiful place when there is a plethora of colors, shapes, ideas, beliefs, and points of views. 


\section{REFERENCES}

ARAFA, Mohamed. Vive la République, Vive la France: Macron's Foreign Policy in Muslim and Middle Eastern World. Jurist Commentary, June 22, 2017. Available at: <http://www.jurist.org/forum/2017/06/Mohamed-Arafa-vive-la-republique.php>.

BAUMANN, Lisa. Seattle Judge Who Halted First Trump Travel Ban Not Ready to Rule on Second One Originally. The Associated Press, Mar. 11, 2017. Available at: <http://www.seattletimes.com/ seattle-news/seattle-federal-judge-not-ready-to-rule-on-blocking-new-travel-ban/>.

BBC. Trump Travel Ban: Questions About the Revised Executive Order. BBC News, July 14, 2017. Available at: <http://www.bbc.com/news/world-us-canada-39044403>. Last visited: 20. sept. 2017.

BEYDOUN, Khaled. Donald Trump: The Islamophobia President (Trump rose to power with an Islamophobic campaign and Islamophobia now will become his official policy). Aljazeera, Nov. 9, 2016. Available at: <http://www.aljazeera.com/indepth/opinion/2016/11/donald-trump-islamophobia-president-161109065355945.html>.

BOWERMAN, Mary Bowerman. Watch: Sally Yates and Ted Cruz Go Head-to-Head on Trump's Travel Ban. USA Today, May 9, 2017. Available at: <https://www.usatoday.com/story/news/ politics/onpolitics/2017/05/09/sally-yates-and-ted-cruz-go-head-to-head-trumps-travel -ban/314018001/>.

CARASIK, Lauren. The Muslim Ban: Did Trump Really Win? The US Supreme Court's Decision Does Not Put Trump's Original Travel Ban Fully in Effect. Here is Why. Aljazeera, June 27, 2017. Available at: <http://www.aljazeera.com/indepth/opinion/2017/06/muslim-ban-trump -win-170627090639940.html>.

EIVEN, Mitch. Trump Promised to Make America Great Again. May be He Will. Then Again? Democracy Guardian, Mar. 2, 2017. Available at: <https://democracyguardian.com/ trump-promised-to-make-america-great-again-maybe-he-will-then-again-6539d7cbe46d>.

FINER, Jon. Sorry, Mr. President: The Obama Administration Did Nothing Similar to Your Immigration Ban. Foreign Policy, Jan. 30, 2017. Available at: <http://foreignpolicy.com/2017/01/30/ sorry-mr-president-the-obama-administration-did-nothing-similar-to-your-immigration-ban/>. Last visited: 20 sept. 2017.

FOSTER, Alice. What are the Countries Donald Trump is Banning Travel From? And What Are His Reasons? Express, June 27, 2017. Available at: <http://www.express.co.uk/news/world/761087/ Donald-Trump-immigration-ban-what-seven-countries-reasons-US-banning-Muslim-travellers $>$. Last visited: 20 sept. 2017.

GEORGE, Varghese K. Original Travel Ban Should Have Stayed, Says Donald Trump. The Hindu, June 5, 2017. Available at: <http://www.thehindu.com/news/international/original-travel-ban -should-have-stayed-says-donald trump/article18724064.ece $>$. 
JOHNSON, Jenna; HAUSLOHNER, Abigailr. 'I Think Islam Hates Us': A Timeline of Trump's Comments About Islam and Muslims. The Washington Post, May 20, 2017. Available at: <https:// www.washingtonpost.com/news/post-politics/wp/2017/05/20/i-think-islam-hates-us-a-timeline -of-trumps-comments-about-islam-and- muslims/?utm_term=.dc6b9f635ea1 >. Last visited: 20 sept. 2017.

LING, Sin Yen. Make America Great Again-to the Exclusion of Muslims and Immigrants. Clearinghouse Community, May 6, 2017. Available at: <http://povertylaw.org/clearinghouse/reruns/ immigrants>.

LIPTAK, Adam Liptak; FLEGENHEIMER, Matt, Neil Gorsuch Confirmed by Senate as Supreme Court Justice. The N.Y. Times, Apr. 7, 2017. Available at: <https://www.nytimes.com/2017/04/07/us/politics/neil-gorsuch-supreme-court.html>.

MARK, Michelle. It's Not a Muslim Ban:Trump Defends Controversial Executive Order on Refugees as Protests Erupt. Business Insider, Jan. 28, 2017.

PIEPER, Moritz. Donald Trump's Travel Ban and Barak Obama's Visa Restrictions Are Not the Same. NewsWeek, Feb. 1, 2017. Available at: <http://www.newsweek.com/obama-trump-travelban-visa-restrictions-threat-us-551085>.

QIU, Linda. Why Comparing Trump's and Obama's Immigration Restrictions Is Flawed. PolitiaFact, Jan. 30, 2017. Available at: <http://www.politifact.com/truth-o-meter/statements/2017/jan/30/ donald-trump/why-comparing-trumps-and-obamas-immigration-restri/>.

REINL, James, Trump's Muslim Ban Comes into Effect ("As ban on visitors from six Muslim-majority countries kicks in, US-based families of those affected express resentment"). Aljazeera, June 29, 2017. Available at: <http://www.aljazeera.com/news/2017/06/trump-muslim-ban-redefining-family-170629193344749.html>.

SAMPATHKUMAR, Mythili. Muslim Travel Ban: US Supreme Court to Rule on Donald Trump's Controversial Policy [Campaign promise hangs in balance after President suffers defeats in lower courts]. Independent, June 25, 2017. Available at: <http://www.independent.co.uk/news/world/ americas/us-politics/us-supreme-court-donald-trump-muslim-travel-ban-ruling-a7807791. html>.

SHEAR, Michael D.; LIPTAK, Adam. Supreme Court Takes Up Travel Ban Case, and Allows Parts to Go Ahead. The N.Y. Times, June 26, 2017. Available at: <https://www.nytimes.com/2017/06/26/ us/politics/supreme-court-trump-travel-ban-case.html>.

SIEGEL, Jonathan R. Siegel. The Inexorable Radicalization of Textualism. University of Pennsylvania Law Review, Philadelphia, v. 158, n. 1, p. 117-178, dec. 2009.

TAYLOR, Jessica. Obama Criticizes Trump's Travel Ban, Says 'Values Are At Stake'. NPR, Jan. 30, 2017. Available at: <http://www.npr.org/2017/01/30/512487565/obama-criticizes-trumps-immigration -ban-heartened-by-protests $>$. 
THE WHITE HOUSE. Executive Order No. 13769 in the Federal Register, Protecting the Nation from Foreign Terrorist Entry into the United States (signed by Donald J. Trump on January 27, 2017). The Office of Press Secretary, Jan. 27, 2017. Available at: <https://www.whitehouse.gov/the -press-office/2017/01/27/executive-order-protecting-nation-foreign-terrorist-entry-united-states $>$. Last accessed: 20 sept. 2017.

U.S. Supreme Court Allows Partial Travel Ban to Take Effect Pending Appeals in October (90-day ban on travelers from 6 mostly Muslim nations stands, unless people can prove U.S. family connection). The Associated Press, June 26, 2017. Available at: <http://www.cbc.ca/news/world/ supreme-court-travel-ban-1.4177987>.

UN High Commissioner for Refugees (UNHCR). The 1951 Convention relating to the Status of Refugees: Its Relevance in the Contemporary Context, Feb. 1999. Available at: <http://www.refworld.org/docid/3ae6b3388.html>. Last visited: 20 sept. 2017.

VOGUE, Ariane. Supreme Court Says Grandparents, Relatives Can Enter US Despite Travel Ban. CNN, July 19, 2017. Available at: <http://edition.cnn.com/2017/07/19/politics/supreme-court-travel-ban-grandparents/index.html>.

WOLF, Richard; GOMEZ, Alan. Supreme Court Reinstates Trump's Travel Ban, But Only for Some Immigrants. USA Today, June 26, 2017. Available at: <https://www.usatoday.com/story/news/ politics/2017/06/26/supreme-court-reinstates-president-trumps-travel-ban/103134132/>. 